\title{
PENTINGNYA CUCI TANGAN PAKAI SABUN \\ UNTUK MEMINIMALISIR VIRUS COVID 19
}

Nur Rahman Nugroho

D3 RADIOLOGI

IIK STRADA INDONESIA

\begin{abstract}
ABSTRAK
Covid-19 adalah keluarga besar virus yang menyebabkan infeksi saluran pernapasan atas ringan hingga sedang. penularannya melalui mata, hidung dan mulut. Cara mengantisipasi peningkatan penyebaran dan jumlah infeksi, masyarakat dihimbau untuk melakukan pola hidup sehat baru sesuai protokol kesehatan salah satunya dengan menjaga kebersihan dengan mencuci tangan dengan sabun. Dalam kehidupan sehari hari mungkin ada Sebagian masyarakat yang mengabaikan pentingnya cuci tangan dengan sabun sebagai salah satu pencegahan virus covid 19.
\end{abstract}




\section{LATAR BELAKANG}

Perilaku cuci tangan pakai sabun merupakan bagian dari program Perilaku Hidup Bersih dan Sehat (PHBS) di rumah tangga. Program PHBS dilaksanakan sebagai upaya pemberdayaan anggota rumah tangga agar sadar, mau, dan mampu melakukan kebiasaan hidup bersih dan sehat. Dengan menjalankan perilaku-perilaku melakukan PHBS, masyarakat berperan aktif dalam gerakan kesehatan di masyarakat seperti memelihara dan meningkatkan kesehatan, mencegah risiko terjadinya penyakit, dan melindungi diri dari ancaman penyakit (Depkes RI, 2009).

Mencuci tangan pakai sabun adalah salah satu upaya pencegahan melalui tindakan sanitasi dengan membersihkan tangan dan jari jemari menggunakan air dan sabun. Tangan manusia seringkali menjadi agen yang membawa kuman daan menyebabkan patogen berpindah dari satu orang atau dari alam ke orang lain melalui kontak langsung atau tidak langsung. (Depkes, 2009; Wagner \& Lanoix)

Lalu kapan waktu yang tepat untuk kita mencuci tangan? Menurut Center For Disease Control and Prevention ( CDC ) berikut adalah saat yang tepat untuk mencuci tangan :

- Sebelum,saat,dan sesudah menyiapkan makanan

- Sebelum dan setelah makan

- Sebelum menyusui bayi

- Sebelum dan setelah mengasuh orang yang sakit di rumah

- Setelah buang air

- Setelah batuk dan bersin

- Setelah menyentuh sampah

- Setelah beraktivitas seperti mengetik,menyentuh uang,hewan/binatang,berkebun,dll 


\section{MASALAH}

Terkadang kita dalam kehidupan sehari hari mungkin agak malas untuk mencuci tangan, Sebagian orang menganggap cuci tangan itu tidak penting, mereka hanya cuci tangan pakai sabun kalau tangannya kotor, berminyak, bau, kalau tidak kotor atau bau dia akan menganggap tangannya bersih (Kompas, 2011). Jika setiap warga masyarakat telah memilki kesadaran diri khususnya dalam membiasakan diri untuk selalu mencuci tangan dengan sabun, angka kesakitan yang saat ini masih tergolong tinggi bisa ditekan atau diminimalisir sekecil mungkin,Bagaimanakah cara cuci tangan yang baik dan benar?

\section{TINJAUAN PUSTAKA}

Menjaga kebersihan diri selama masa pandemi Corona virus seperti mencuci tangan merupakan salah satu langkah yang perlu dilakukan masyarakat. World Health Organization (WHO) juga telah menjelaskan bahwa menjaga kebersihan tangan telah mampu menyelamatkan nyawa manusia dari infeksi Corona virus (World Health Organization, 2020). Mencuci tangan tidak bisa dilakukan dengan sembarangan oleh masyarakat. Mencuci tangan dengan benar dalam waktu 20 detik atau lebih menggunakan air mengalir dan sabun cair merupakan cara efektif yang dianjurkan dan sangat perlu masyarakat terapkan (Khedmat, 2020). Tindakan mencuci tangan dapat memutus siklus transmisi dan resiko penyebaran Corona virus antara $6 \%$ dan $44 \%$ dapat dikurangi (Chen et al., 2020). Menurut Depkes RI (2007), masyarakat harus mengetahui bagaimana mencuci tangan dengan air dan sabun dengan benar. Air yang tidak bersih banyak mengandung kuman dan bakteri penyebab penyakit, dan apabila digunakan maka kuman akan berpindah ke tangan. Pada saat makan, kuman dengan cepat masuk ke dalam tubuh, yang bisa menimbulkan penyakit. Sabun dapat membersihkan kotoran dan membunuh kuman, karena tanpa sabun kotoran dan kuman masih tertinggal di tangan. 


\section{PEMBAHASAN}

Adapun delapan langkah mencuci tangan yang baik dan benar yaitu :

- Keran air dibuka dan kedua tangan dibasahi.

- Sabun di tuangkan secukupnya, kemudian dioleskan pada kedua tangan, hingga menutupi seluruh permukaan tangan.

- Kedua telapak tangan digosok secara bergantian, sela-sela jari-jari tangan, sela kuku dan punggung tangan hingga bersih.

- Ujung jari dibersihkan secara bergantian dengan cara mengatupkannya.

- Kedua ibu jari tangan dibersihkan secara bergantian dengan menggenggam dan memutar ibu jari secara bergantian.

- Ibu jari gosok secara berputar dalam genggaman tangan dan dilakukan pada kedua tangan,

- Ujung jari diletakkan pada telapak tangan, dan digosok perlahan secara berputar, dilakukan secara bergantian dengan tangan lainnya.

- Kemudian kedua tangan dibilas dengan air yang mengalir, dan segera kedua tangan dengan dikeringkan menggunakan handuk, tisu kering atau dengan menggunakan hand drying

. Sebagaimana telah menjadi pengetahuan umum (well-known) tangan adalah anggota badan yang kerap membawa dan menularkan bibit penyakit. Bahkan penyebaran covid-19 ini juga salah satunya melalui tangan. Jika terkontaminasi dengan penderita, maka tangan yang telah terkontaminasi akan menyentuh hidung, mata dan mulut. Dari tiga aera ini, maka Covid-19 akan masuk ke organ paru dan kemudian virus akan merusak sistem paru yang pada akhirnya membuat seseorang sesak nafas dan jika system imun nya rendah, maka akan menyebabkan gagal pernafasan. Protokol kesehatan merupakan cara yang perlu diterapkan untuk mencegah penyebaran kasus infeksi Corona virus. Hal tersebut perlu dilakukan karena belum ditemukannya antiviral spesifik yang dapat digunakan sebagai vaksin (Gennaro et al., 2020., Yuliana, Y. 2020). Oleh karena itu masyarakat perlu untuk tahu dan menerapkan beberapa protokol kesehatan selama masa pandemi Corona virus. Salah satu protokol kesehatan yaitu dilakukan adalah cuci tangan dengan sabun. Menurut WHO hal ini adalah cara yang tepat sesuai kesehatan, menurut Riris (2009) karena sabun dapat membunuh kuman atau virus yang menempel di tangan. Maka usaha yang paling sederhana untuk menegakkan pilar hidup sehat adalah dengan gemar cuci tangan. Usaha yang oleh masyarakat dianggap sepele ini ternyata dapat ber kontribusi penting pada upaya pencegahan Covid-19 


\section{KESIMPULAN}

Setelah mengetahui cara mencuci tangan pakai sabun yang baik dan benar diharapkan kitab isa mengikuti cara tersebut sebagai salah satu cara untuk meminimalisir penyebaran covid 19

\section{DAFTAR PUSTAKA}

Suryani, S. I., \& Sodik, M. A. (2018). Perilaku Cuci Tangan Pakai Sabun.

Ambarwati, E. R., \& Prihastuti, P (2019) 'Gerakan Masyarakat Hidup Sehat (Germas) Mencuci Tangan Menggunakan Sabun Dan Air Jurnal Binakes; Volume 1 no 1 Tahun 202032 Mengalir Sebagai Upaya Untuk Menerapkan Perilaku Hidup Bersih Dan Sehat (Phbs) Sejak Dini’, Jurnal Pengabdian Kepada Masyarakat, 1(1) : 45-52.

Departemen Kesehatan RI. (2011). Cuci Tangan Pakai Sabun Dapat Mencegah Berbagai Penyakit. 